Egyptian Journal of Aquatic Biology \& Fisheries

Zoology Department, Faculty of Science,

Ain Shams University, Cairo, Egypt.

ISSN $1110-6131$

Vol. 24(6): 73 - 102 (2020)

www.ejabf.journals.ekb.eg

\title{
Monograph of the Egyptian Octopuses \\ Order: Octopoda (Cephalopoda: Mollusca). Part III
}

\author{
Rafik Riad \\ Rafik_riad@yahoo.com
}

\section{ARTICLE INFO}

Article History:

Received: June, 22, 2020

Accepted: Aug. 25, 2020

Online: Aug. 28, 2020

Keywords:

Monograph

Octopuses

Egypt

Mediterranean Sea

Red Sea

Mollusca

\begin{abstract}
The cephalopods are known to be commercially and ecologically important around the world. Class Cephalopoda is made up of four major groups, Cuttlefishes, Squids, Octopuses, and Nautilii. The first three groups are present in Egypt in the Mediterranean Sea and in the Red Sea and constitute a main component in the fisheries industry in Egypt. In order to understand the biology and ecology of any species, their identification should be conducted properly to maximize the accuracy of any study. The present monograph is prepared to demonstrate an identification key for the octopus species of the order Octopoda in the Egyptian waters. This is the third publication demonstrating a first-in-kind identification key for the three major cephalopod groups. The first monograph was about the cuttlefishes and the second was about the squids.

Six Egyptian Octopus species (Order: Octopoda (Cephalopoda: Mollusca) were recorded; Octopus vulgaris, Octopus macropus, Eledon moschata, Octopus defilippi, Octopus aegina and Octopus membranaceus. Three of them Octopus vulgaris, Octopus macropus and Eledon moschata were recorded in Alexandria in the Mediterranean Sea, while Octopus aegina and Octopus membranaceus were recorded in The Gulf of Suezin TheRed sea. Finally, three species; Octopus vulgaris, Octopus macropus and Octopus defilippi were recorded in both seas. The identification was conducted by means of morphological features and for this purpose, key structures of individuals from each species were dissected and drawn by means of a zoom stereoscopic microscope provided with a Camera Lucida drawing tube. The specimen structures were also photographed by a Canon Digital Camera.
\end{abstract}

\section{INTRODUCTION}

Octopuses, cuttlefishes, squids and nautilii are important representatives of the class Cephalopoda. They play an important role in the sea food industry and also represent one of the main sources of protein food. The Cephalopods belong to the third trophic position in the food chain and progress one or two stages with age (Clark, 1966). All are carnivorous. They prey on a variety of crustacean and fish organisms.

They themselves can be preys of diving birds, pelagic and benthic fish's seals and whales. It is reported that more than hundred million ton of oceanic squids are consumed per year by the humpback whales (Clark, 1966). As a group, they include the largest 
species of both modern and fossil invertebrates in both the coastal and oceanic waters, inhabiting different kinds of grounds. Commercially, they represent a remarkable and significant fishery in many areas of the world (Nesis, 1987).

Order Octopoda include two suborders, eleven families, about forty genera and approximately two hundred species (Nesis, 1987). Generally from the total catch of world cephalopod fishery, about $14.6 \%$ were octopuses, $13.6 \%$ cuttlefish and $71.8 \%$ squids (Roper et al., 1984). For the Egyptian Mediterranean fisheries, according to the data of Anon, 1987-1998, octopuses represent an average of $2.12 \%$ of fish landings. From the systematic point of view, octopod cephalopods are poorly resolved. The family Octopodidae, particularly the genus Octopus, is highly specious and taxonomically difficult (Hochberg, et al. 1992). This is because of dearth of hard parts or other reliable morphological characters and the high variability of their morphometric. Classification relies largely on reproductive characteristics of mature males, making females and juveniles difficult to identify, particularly in there preserved state. This poor resolution is reflected in contribution on local cephalopod fauna (Massy 1928; Robson 1930; Voss 1967; Roeleveld 1975) and new species are still being described (Villanueva et al., 1992).

Morphometrics studies could help much in identifying species. Clarke (1962) devised a key to families, within the octopods using only the beaks. Since then two other keys have been published in which the beaks were used to identify octopods to families and in some cases to the species level (Akimushkin, 1963 and Mangold \& Fioroni, 1966). Now it is possible to identify species from characteristic feature of beaks in addition to more precise information about their growth in relation to body weight. Within the last few years a number of techniques have been developed which represent major advances in the ability of the investigator to discriminate variation in the proteins of many species of organisms. These are of potential benefit to physical anthropologists interested in the biochemical variation in human and non-human primates. Most worthy among these new methods are double internal standard disc electrophoresis pioneered by Johnson (N.D), and isoelectric focusing. The latter technique however has not been exploited as a research tool for survey studies. The ability of this method to distinguish differences in free electric mobility among other-wise indistinguishable protein molecules would ordinarily have been adopted by many laboratories, except for practical and fiscal considerations which put this powerful tool out of the reach of modesty funded projects (Byles et al., 1979). Twenty-nine cephalopod species are known to occur in the Mediterranean Sea and of these; twenty-four species are known to extend to the Eastern Mediterranean basin, of which eight are Octopoda species (Roper et al., 1984). In the Egyptian waters, Robson (1926) recorded six cephalopod species from the Suez Canal. In the Mediterranean water Steuer (1939) recorded only one species, Sepia officinales from Abu Qir Bay. From the total catch of world cephalopod fishery about $14.6 \%$ were octopuses. (Roper et al., 1984). Riad (1993) recorded nine cephalopod species off Alexandria Mediterranean waters, three of them were octopuses, two cuttlefishes and four squids. The octopus species recorded are Octopus vulgaris, Octopus macropus and Eledone moschata generally octopuses which are the subject of our work are found throughout the world's tropical and temperate ocean (Robson, 1929). Riad et al. (1997) studied the development of Octopus vulgaris from Alexandria Mediterranean waters. Saad and Emam (1998). Studied the poisonous salivary glands of Octopus vulgaris from the Mediterranean Sea, Riad (2000a)studied the biology and the morphometry of three 
octopoda species Octopus vulgaris, Octopus macropus and Eledone moschata from the Alexandria Mediterranean waters. Riad (2000a) used the isoelectric focusing technique for identification of the three octopoda species Octopus vulgaris, Octopus macropus and Eledone moschata. Riad (2000b) recorded one first record Octopoda species Octopus defilippi from Alexandria Mediterranean waters. Nessim and Riad (2003) studied the bioaccumulation of heavy metals in Octopus vulgaris from Alexandria Mediterranean waters. Ibrahim et al. (2006) studied the molecular phologeny of three octopodid species from the Mediterranean waters. Riad and Gabr (2007) studied the comparative study on Octopus vulgaris from Mediterranean and Red Sea of Egypt. Riad (2008) recorded 10 cephalopod species from Suez Gulf and Red Sea, 5 of them were Octopoda species.There are Octopus defilipii, Octopus aegina, Octopus membranaceus, Octopus vulgaris and Octopus macropus Elganainy and Riad (2008) studied the population structure of Octopus defilippi from Suez Gulf, Red Sea. Emam et al. (2008) studied macro and microscopic structure of the digestive system of Octopus vulgaris from Alexandria Mediterranean waters. Riad and Kilada (2012) studied the reproductive biology of Eledone moschata from the Alexandria Mediterranean waters. Osman et al. (2014) studied the Feeding biology and biochemical composition of the lessepsian migrant Octopus aegina from Gulf of Suez, Red Sea.

Riad (2020a) published the first monograph of the cephalopod identification and focused on the Egyptian cuttlefishes. Riad (2020b) published the second monograph focused on the Egyptian squids. The present monograph was prepared to address the identification of octopuses in the Egyptian waters, using morphological features.

\section{MATERIALS AND METHODS}

Specimens were obtained from fishing trawlers operating in Egyptian Mediterranean Sea and Suez Gulf, Red Sea. Specimens were also obtained from Alexandria and Suez fish markets.

According to Roper et al. (1984), the following characters were carefully examined for the identification of the species: External morphology, hectocotylized arm, arm sucker, radula, gill, shell and funnel (siphon).

Specimen parts were drawn by means of a zoom stereoscopic microscope provided with a Camera lucida drawing tube. The specimen parts were also photographed by a Canon digital Camera.

\section{RESULTS AND DISCUSSION}

Six octopus species Order: Octopoda ( Cephalopoda: Mollusca) were recorded in the present monograph.

Octopoda of the Egyptian waters (Mediterranean and Red Sea).

The following six Egyptian octopus species Order: Octopoda (Cephalopoda: Mollusca) were illustrated in the present monograph as follows:

\section{Phylum: Mollusca}

Class : Cephalopoda Cuvier, 1798.

Subclass : Coleoidea Bather, 1888.

Order : Octopoda Leach, 1818. 
Suborder: Incirrata Grimpe, 1916.

Family: Octopodidae d'Orbigny, 1845.

Subfamily : Eledoninae Gray, 1849.

Genus Eledone Leach, 1817.

Eledone moschata Lamarck, 1798. Alexandria, Mediterranean waters.

\section{Subfamily: Octopodinae}

Genus Octopus Lamarck, 1798.

1- Octopus vulgaris Cuvier, 1797. Alexandria, Mediterranean waters and. Suez Gulf, Red Sea.

2- Octopus macropus Risso, 1826. Alexandria, Mediterranean waters and Suez Gulf, Red Sea.

3- Octopus defilippi Verany, 1851. Alexandria, Mediterranean waters and Suez Gulf, Red Sea.

4- Octopus aegina Gray, 1849. Suez Gulf, Red Sea.

5- Octopus membranaceus Quoy\&Gaimard, 1832. Suez Gulf, Red Sea.

Order : Octopoda Leach, 1818

The order Octopoda is divided into two suborders; Cirrata, mostly deep sea pelagic and epibenthic forms which possess cirri along the arms and have paddle shaped fins and Incirrata, moderately deep to shallow-living benthic and epipelagic forms which possess neither cirri nor fins. Only the Incirrata are of commercial interest, with some Octopus species. Eight circumoral arms, no tentacles; fins sub terminal (on sides of mantle), widely separated, or absent; shell reduced, vestigial, "artilaginous",or absent; suckers without chitinous rings, set directly on arms without stalks; eye open to sea with primary and secondary (concentric) lids; branchial canal present on gills between downfolded filaments (some exceptions); liver a single with incorporated pancreas; central (rachidian) tooth of radula with one large projection and two or more small lateral cusps, first and second lateral teeth multicuspid; buccal memberane absent; olfactory organ a ciliated pit (Roper et al.,1984). This order is represented by one suborder in the Egyptian waters Incirrata Grimpe, 1916.

Suborder: Incirrata Grimpe 1916.

Eight arms with suckers only, no cirri, fin absent. The web is usually shallow. (Roper et al., 1984). Only one of the eight families, Octopodidae d'Orbigny, 1845 is represented in Egyptian waters.

Family: Octopodidae d'Orbigny, 1845

This family has inflated bodies. They have rather small heads; prominent eyes protected by eye-lids, fleshy lips to their mouths, and strongly curved compressed beaks. Their arms are eight in number, and all similar though more or less unequal; they bear sessile suckers. The mantle is always attached to the neck. The members of this group have no internal shell. They are active animals, swimming and creeping with facility, but living chiefly among the crevices of rocky ground. Most species with a W or VV shaped funnel organ. Three subfamilies are known: Eledoninae Gray, 1849; Octopodinae Grimpe, 1921; and Bathypolypodinae Robson, 1929. (Roper et al., 1984). The first two Subfamilies are represented in the Egyptian waters. The subfamily Eledoninae embraces 4 genera one only of them is represented in this study: Eledone Leach, 1817, while the 
subfamily : Octopodinae Grimpe, 1921 embraces 10 genera, one of them only is represented in this study: Octopus Lamarck, 1798.

Subfamily: Eledoninae Gray, 1849.

Arms with one row of suckers(Roper et al., 1984).

Genus: Eledone Leach, 1817

Body oval; head furnished with eight nearly equal arms, provided with sessile suckers in a single row on their inner sides. Ink sac presents (Roper et al., 1984). This genus is represented by one species in the present monograph: Eledone moschata Lamarch. 1798.

Eledone moschata ( Lamarck, 1798).

(Plates 1, 2 \& 3)

Simonymy: Octopus moschata Lamarck, 1798; Paulpe musque Montfort, 1802: Sepia moschata Bose, 1802; Ozocna moschata Rafinesque, 1814.

World distribution: West Mediterranean Sea, including Adriatic Sea (Roper et al, 1984) East Atlantic Ocean, (Roper et al., 1984) and Namibia, ( Ludertz Bay) Cape-Town, Littoral and upper sub-littoral environments, (Nesis, 1987)

Local name: Okhtaboot, Sabaa dule and Lakakeem. (Riad, 1993).

Local distribution: The species is recorded off Alexandria shore from Abu Qir Bay (5070 m. depth), El-Agamy (25-54 m. depth), Sidi-Abdel Rahman, (40-80 m. depth), off ElMontazah (50 m. depth), Sidi Kreer (40-50 m. depth), El-Max (40 m. depth), off Keyed Bay (40 m. depth) and is common on Alexandria fish markets

(Anfushy, Abu Qir, Maadeia and Rosetta) (Riad, 1993).

Description: The mantle is ovoid, more or less broad and rounded posteriorly. The head is narrower than the mantle. The eight arms are equal, provided with uniserial suckers, the arms are united at their bases by a strong web, which connects them for some distance, about $33 \%$ of the total arm length (Plate 1). The tip of the male normal arms are divided into two rows of flattish laminae 45 to 60 pairs, (Plate 2 a and plate 3 a). The length of right armIII of male hectocotylized is about $65 \%$ of the normal arms and the ligula occupies about $3 \%$ of the arm length (Plate $2 \mathrm{j}$ and plate $3 \mathrm{k}$ ). Calimus absent, the gill is provided with eleven-gill lamellae (Plate $2 \mathrm{~g}$ and plate $3 \mathrm{c}$ ). Over each eye single cirrus is observed, and a blackish brown blotch on the dorsal side of the smooth skin (Plate 1).

Eledone moschata can be distinguished from Octopus vulgaris and Ocetopus macropus by the possession of one row of suckers on each arm and clear cirri over each eye. The morphology of Eledone moschata from Alexandria Mediterranean waters is in agreement with the literatures, except for the following character, that the number of flattish laminae of the male normal arm. Of specimens collected, the largest specimens had a mantle length of $12.6 \mathrm{~cm}$. for male and $11.2 \mathrm{~cm}$. for female, total length $59.5 \mathrm{~cm}$. for male and $51.2 \mathrm{~cm}$. for female, and total weight of $566 \mathrm{~g}$. for male and $364 \mathrm{~g}$. for female. Fischer, (1973) measurement for total length was in the same range recorded (50$60 \mathrm{~cm}$.). The mantle length and total length of the present specimens are smaller than given by Roper et al. (1984) while total length is remarkably bigger $(35 \mathrm{~cm}$.). The minimum sized specimens showed a mantle length of $4.6 \mathrm{~cm}$. for male and $4.4 \mathrm{~cm}$. for female, total length $18 \mathrm{~cm}$. for both sexes and total weight $37 \mathrm{~g}$. for male and $25 \mathrm{~g}$. for female. 
Habitat: On muddy sandy gravelly bottoms and also dwelling in cavities. Depth range from 10 to 300m., (Robson, 1912 and Roper et al., 1984).

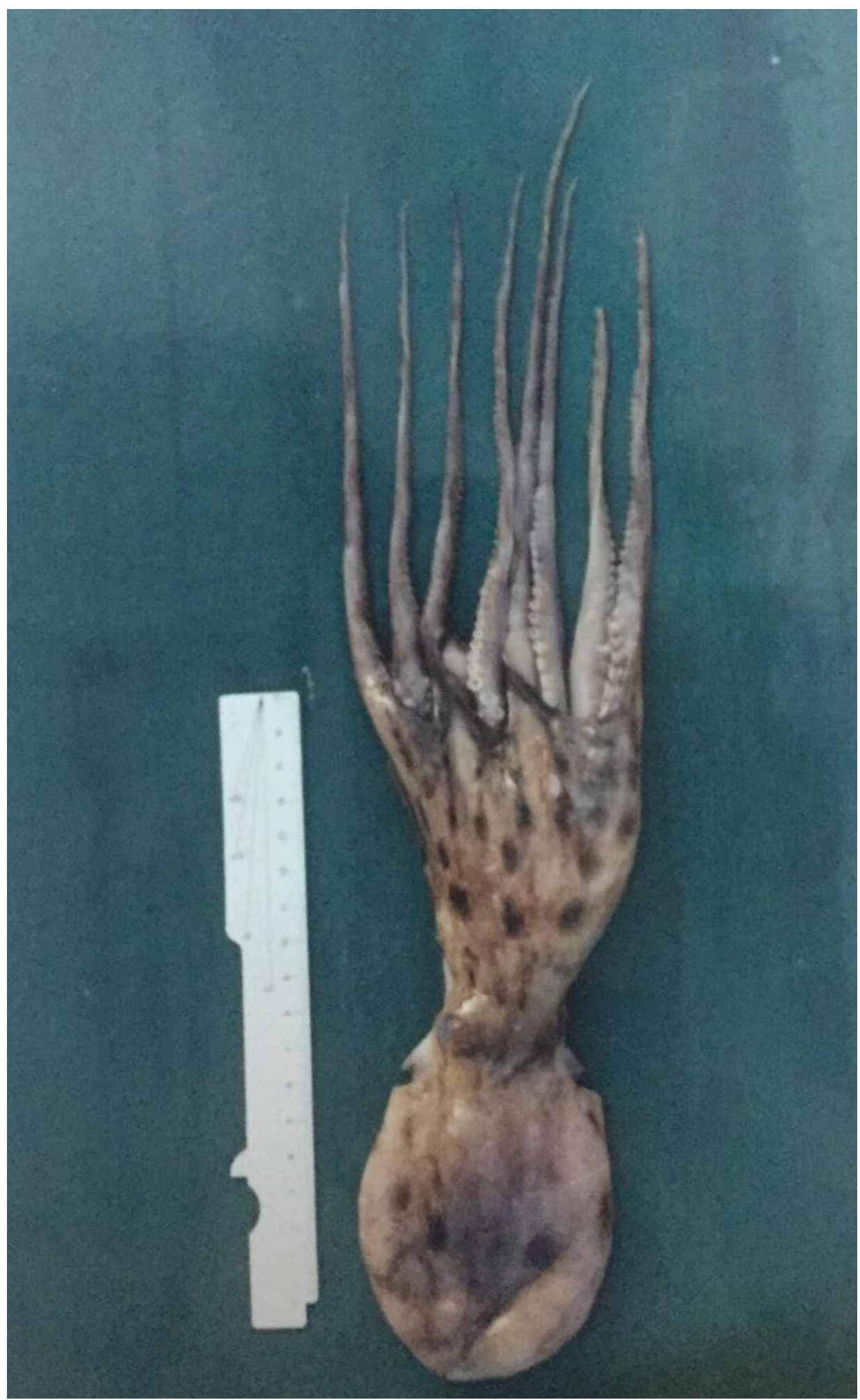

Plate (1) Eledone moschata 


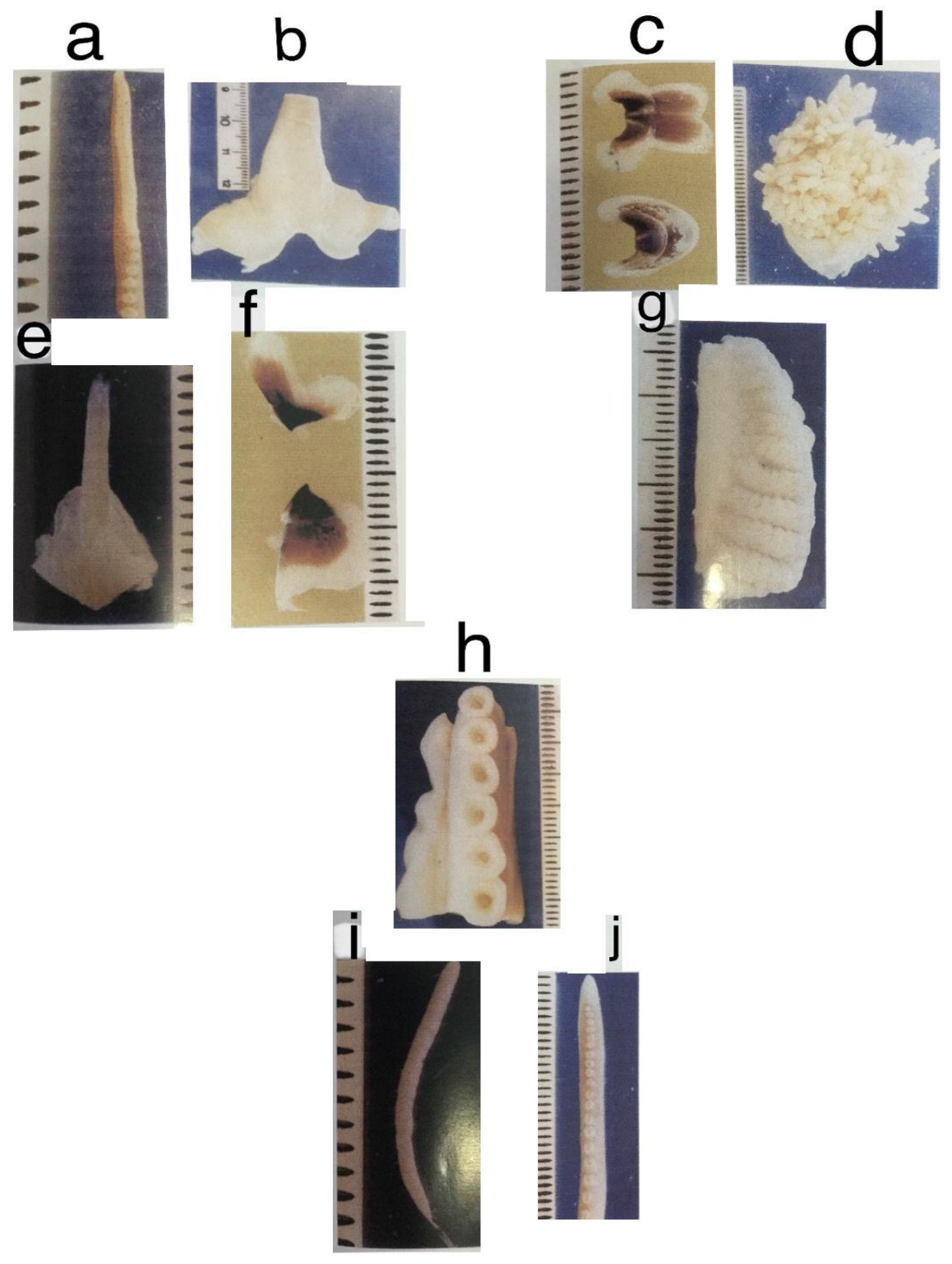

Plate (2) Eledone moschata

A- Male normal arm. B- Funnel. C- Upper \& Lower beaks. (Dorsal view). D-Egg cluster. E- Radula. $\quad$ F- Upper \& Lower beaks. (Lateral view). G- Gill. H- Part of arm. iSpermatophore. j-Right arm III of male hectocotylized. 

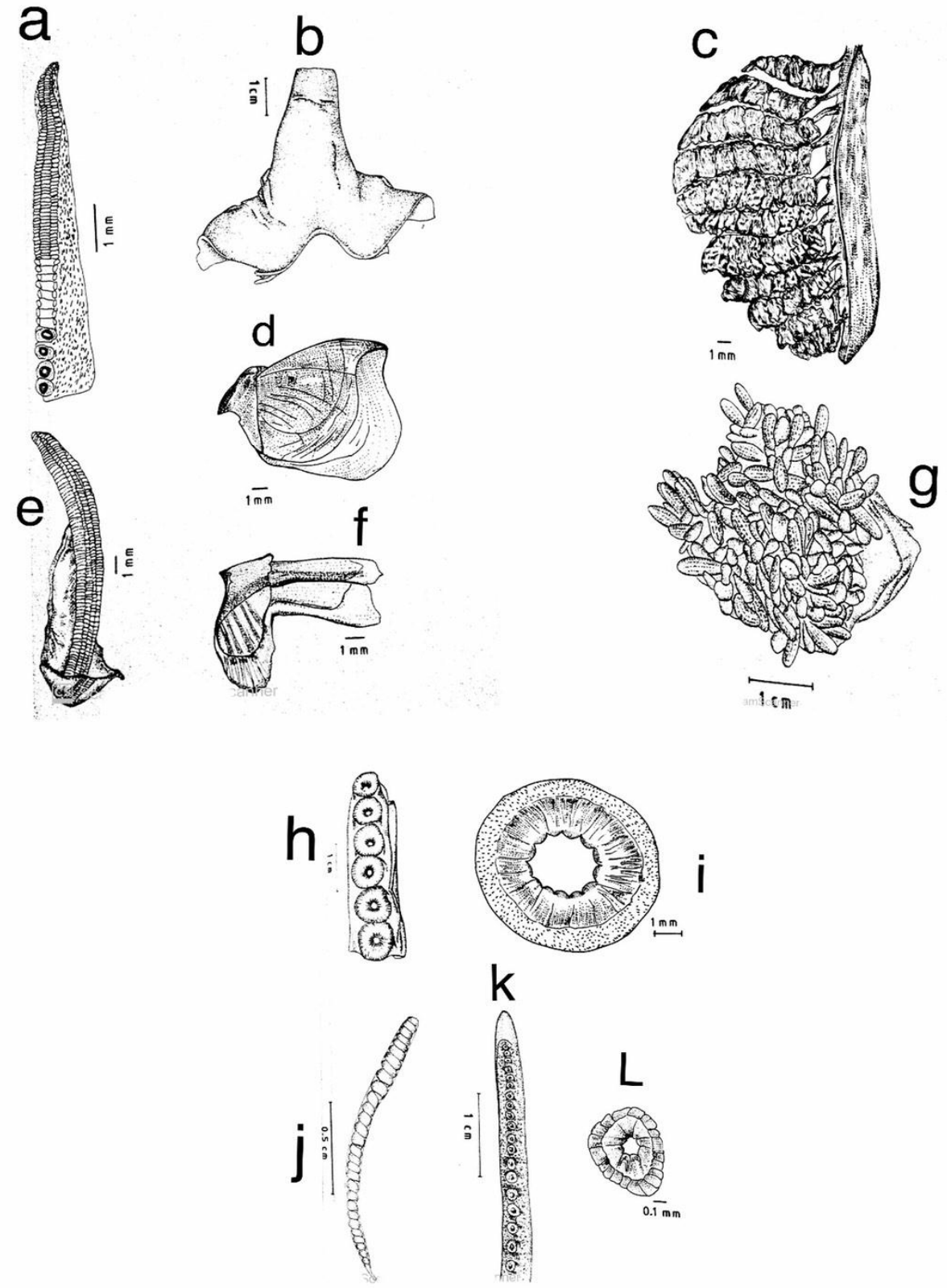

\section{Plate (3) Eledone moschata}

A-Male normal arm. B- Funnel. C- Gill. D- Upper beak. E- Radula. F- Lower beak. GEgg cluster. H- Part of arm. I- Arm sucker. J- Spermatophore. K- Right arm III of male hectocotylized. L- Small arm sucker. 


\section{Subfamily : Octopodinae}

Ink sac present, sometimes small and deeply buried in liver, but ink always secreted. Arms with two rows of suckers (Roper et al., 1984).

Genus: Octopus Cuvier, 1797.

The hectocotylized arm is the third right one. Body firm, more or less muscular. Funnel organ W or VV shaped. Mantle aperture not narrow or slightly narrow. Hectocotylus well developed, with more or less long differentiated ligula and calamus. Mantle aperture wide. No bright color rings scattered over body and arms, no ocellar spots on mantle, only round ocellar spots may be present on web in front of eyes as well as different stripes, spots patterns, etc., rarely coloration uniform (Roper et al., 1984).

The genus is represented in the present study by 5 species namely, Octopus vulgaris, Octopus macropus Octopus defilippi. Octopus aegina and Octopus membranaceus.

Key to the recorded species of genus Octopus in the present monograph

Three cirri over each eye, arms about equal in length, the modified part of arm III of male hectocotylized is very small and spoon shaped, 11 gill lamellae per each gill. ..Octopus vulgaris

The dorsal body is ornamented with white spots, the arms are very long, right arm III of male hectocotylized with a large tubular ligula, extending to about $13-15 \%$ of its length, no cirri over eyes, 12 gill lamellae per each gill,........................octopus macropus Funnel elongate tube, third arms very much longer than other arms, right arm III of male hectocotylized shorter than opposite arm..............................octopus defilippi Mantle covered with fine papillae, arm I are shortest, right arm III of male hectocotylized with short ligula, 5to $8 \%$ of arm length and ligula with very shallow groove, seven gill lamellae per each gill..................................................octopus aegina. Tow cirri over each eye, right arm III of male hectocotylized: ligula slender and long 4 to $6 \%$ of arm length, 7 or 8gill lamellae per each gill. Octopus membranaceus.

\section{Octopus vulgaris Cuvier, 1797. \\ (Plates 4, 5\& 6)}

Synonymy: Sepia rugosa Bosc, 1792; Octopus granulatus Lamarck, 1798 Octopus vulgaris. Lamarck, 1798; Octopus cassiopeia Gray, 1849; Octopus tuberculatus Risso, 1862; Octopus trascheli Targioni- Tozzetti, 1869; Octopus rugosus. Robson, 1929.

world distribution. West Mediterranean Sea, including Adriatic Sea (Roper et al., 1984) Turkish waters, (Catagan and Kocatas, 1990), East Atlantic (Roper et al. 1984). In the Atlantic from Long Island to southern Brazil and from Southern North Sea to the Cape of Good Hope, Common in the Gulf of Mexico and Caribbean Sea, ( Nesis, 1987).

Local name: Okhtaboot, Folby and Sabaa deule ( Riad, 1993).

Local distribution. The specimens were collected off shore from Alexandria waters by commercial fish trawl, Abu Qir Bay (50-70 m. depth), El-Agamy (25-45 m. depth), Elhamra at Sidi Abd- Alrahman (40-80 m. depth), off El-Montazah (50 m. depth), Sidi Kreer. (40-50 m. depth) EL-Max (40 m. depth), off Kayet Bay (40 m. depth). And from commercial fish trawl from Suez Gulf (Ataka Harbor). It is common on Suez and Alexandria fish markets (Anfushy, Abu Qir, Maadeia and Rosetta) (Riad, 1993and Riad,2008).

Description: The body of Octopus vulgaris is oval and small compared with the head and arms, covered with flattened tubercles (Plate 4). The head is large, with prominent 
eyes; three cirri are placed over each eye. The arms are thick and about equal in length, on their inner surface are seen the suckers arranged in double rows (Plate 5 i \& plate $6 \mathrm{k}$ ), the bases of the arms are strongly webbed together. The dorsal pair of arms are shorter than the other arms and the length of the armsare about three times the body length. The modified part of right arm III of male hectocotylized is very small and spoon shaped, the ligula occupies about $2.25 \%$ of its length (plate $5 \mathrm{c} \&$ plate $6 \mathrm{f}$ ). The gill is provided with eleven-gill lamellae, (Plate $5 \mathrm{~d} \&$ plate $6 \mathrm{~g}$ ). Octopus vulgaris is differentiated from Octopus macropus by its shorter arms, the possession of a well-developed interbranchial membrane (connecting the arms up to $1 / 5$ of their length), and the presence of three cirri over each eye. On the other hand, Eledone moschata differs from Octopus vulgaris by having a single row of suckers on the arms and by the presence of only one cirrus over each eye. The morphology of Octopus vulgaris in the present monograph is in agreement with the literatures, except for the following additional characters; three cirri over each eye; this character was only stated by Forbes and Hanley (1852). Of the specimens collected, the largest specimen had a total length of $104 \mathrm{~cm}$. for male and $99.6 \mathrm{~cm}$.-for female. Fischer, (1973) gave a maximum total length 90 to $110 \mathrm{~cm}$. Roper, et al. (1984) reported much larger sizes, total length $130 \mathrm{~cm}$. for male and $120 \mathrm{~cm}$. for female. The largest specimen had a mantle length of $16.5 \mathrm{~cm}$. for male and $13.9 \mathrm{~cm}$. for female and total weight of $2285 \mathrm{~g}$. for male and $1470 \mathrm{~g}$. for female. The smallest specimen caught had a total length of $27.5 \mathrm{~cm}$. for the male and $26 \mathrm{~cm}$. for the female, mantle length of $5 \mathrm{~cm}$. for male and $4.6 \mathrm{~cm}$. for female and total weight of $50 \mathrm{~g}$. for the male and $30 \mathrm{~g}$. for the female.

Habitat: On muddy sandy gravelly bottoms and also dwelling in cavities. Depth range from 10 to 300 m. (Robson,1932 and Roper et al., 1984).

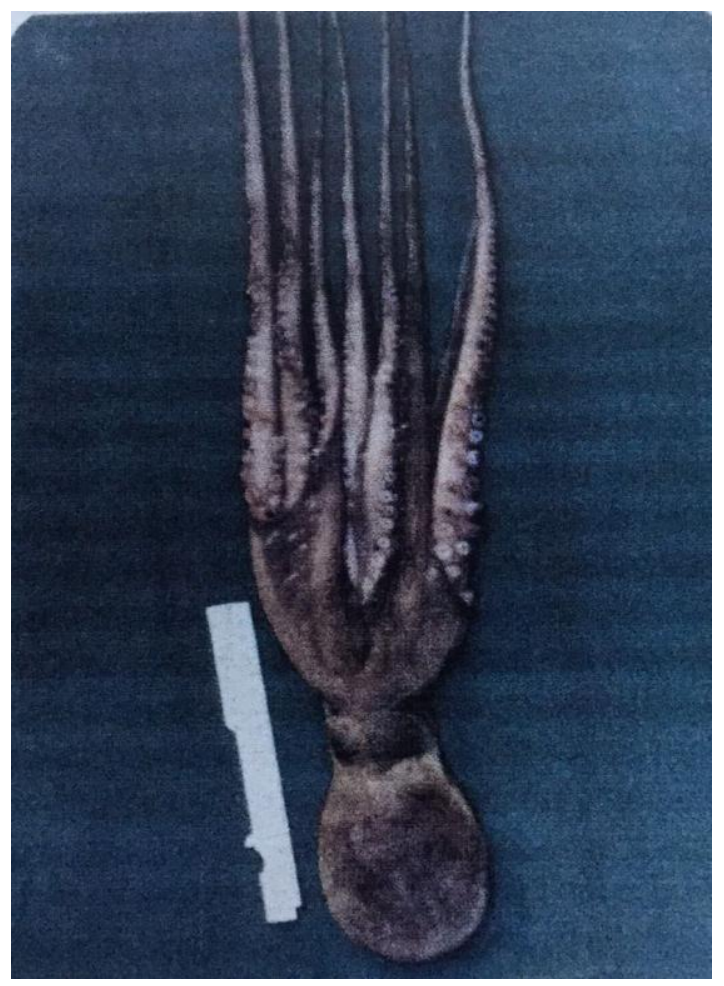

Plate (4) Octopus vulgaris 


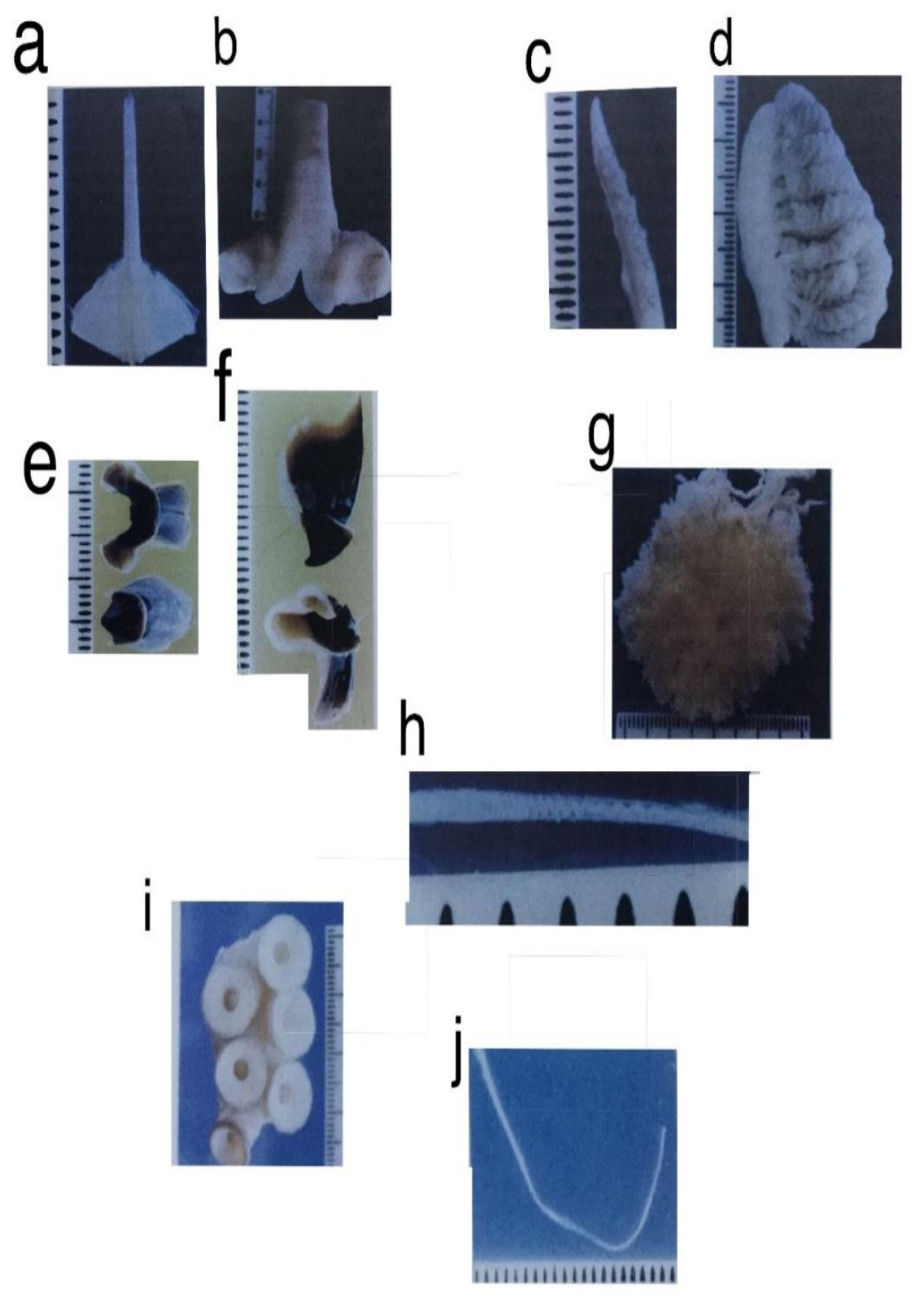

Plate (5) Octopus vulgaris

A- Radula. B- Funnel. C- Right arm III of male hectocotylized . D- Gill EUpper \&lower beaks (dorsal view). F-Upper \&lower beaks (lateral view). G- Egg cluster. H-Magnified part of spermatophore .I-Part of arm.JSpermatophore. 

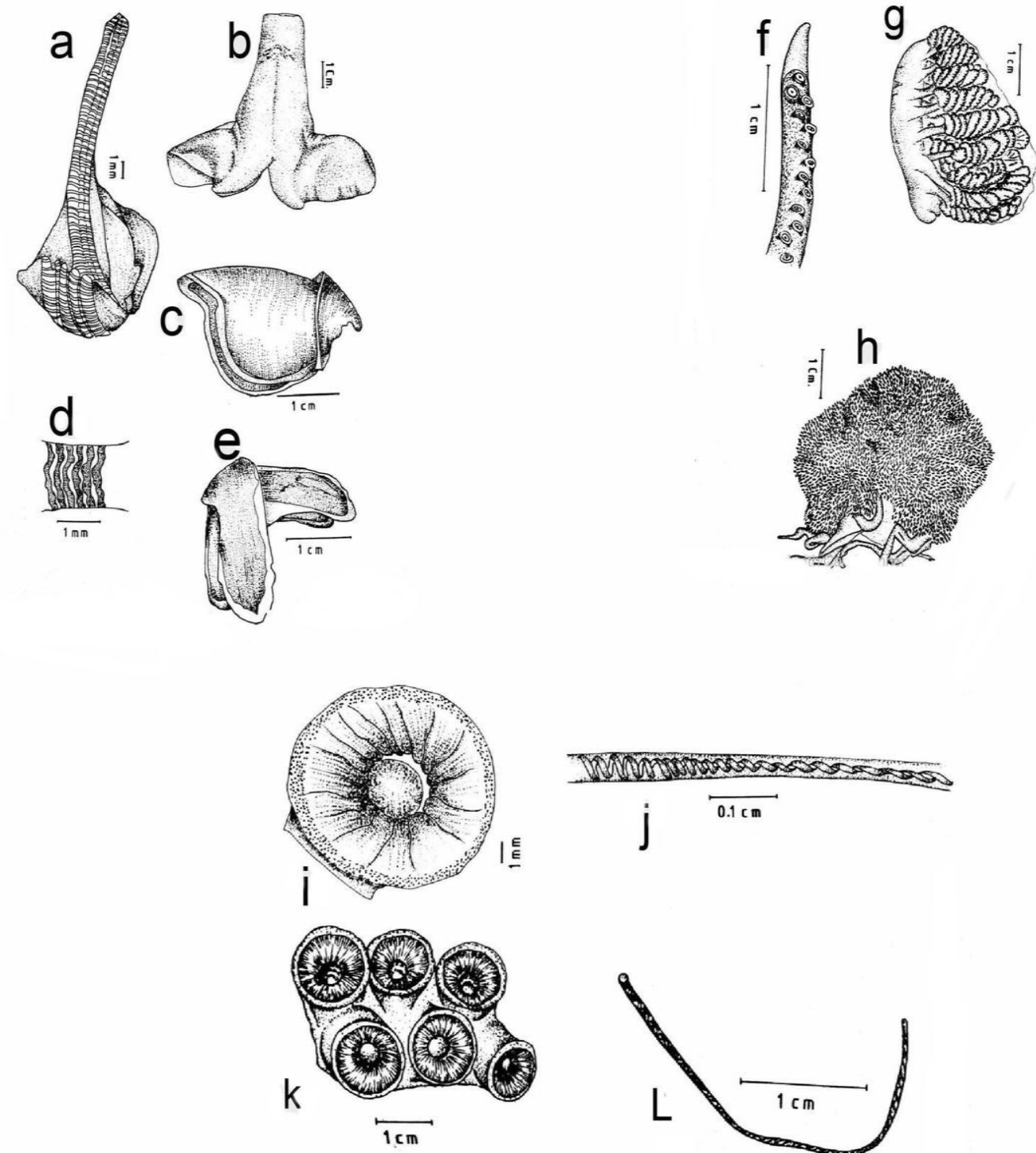

Plate (6) Octopus vulgaris

Radula. B- Funnel. C- Upper beak D- Enlarged part of radula teeth. E- Lower beak. F- Right arm III of male hectocotylized . G- Gill .H- Egg cluster. I- Arm sucker. J- Magnified part of spermatophore. K- Part of arm. L- Spermatophore. 


\section{Octopus macropus Risso, 1797. \\ (Plates 7, 8 \& 9)}

Synonymy: Octopus macropodus, San Giovanni 1829. Octopus cuvieri d'Orbigny, 1840; Octopus longimanus d'Orbigny, 1840; Octopus alderi Verany, 1851.;0ctopus bernudensis Hoyle, 1885; Octopus chromatus Heilprins, 1888.

World distribution: Worldwide in warm waters (Roper et al., 1984). Western and Eastern Mediterranean (Fischer, 1973). Adriatic Sea (Riedle, 1970). North Atlantic, Indian Ocean, Central and Western Pacific Ocean, Gulf of Aqaba (Adam, 1960). North African coast (Fischer, 1973). Tropical Atlantic, Indo-West Pacific species, in the western Atlantic mainly near Bermuda and Bahamas Islands, Southern Florida to Brazil, Caribbean Sea, western Africa to the Gulf of Guinea, Ascension and Santa Helena Islands ( Nesis, 1987).

Local name: Okhtaboot or Sabaa deule and Hebal ( Riad, 1993).

Local distribution: The species was collected by commercial fish trawl off shore from Abu Qir Bay (50-70 m. depth), El-Agamy (25-45 m. depth), Sidi-Abd-Alrahman (40-80 m. depth), off El-Montazah (50 m. depth), Sidi -Kreer (40- 50 m. depth), El-Max (40 m. depth), off Kait Bye $(35 \mathrm{~m}$. depth)and from commercial fish trawl from Suez Gulf(Ataka Harbor),Red Sea. It is common on Suez and Alexandria fish markets (Anfushy, Abu Qir, Maadeia and Rosetta) (Riad, 1993 and Riad, 2008).

Description: The dorsal body is ornamented with white spots. The arms are very long, 67 times longer than the body length (plate7), each has two rows of suckers (plate8g\& plate9j), the first pair of arms I is much longer (Plate 7). Right arm III of male hectocotylized with a large tubular ligula, extending to about 13-15\% of its length (ligula index), (Plate 8a\& plate9a). The cirri over eyes are absent. The gill is provided with 13gill lamellae (plate8f\& plate9c). This species differs from Octopus vulgaris by the following characters. Its slender and longer arms, it's poorly developed interbranchial membrane. Eledone moschata differs from Octopus macropus by its single row of suckers on the arms and by its single cirrus over each eye, while cirri are absent in Octopus macropus. The morphology of Octopus macropus in the present monograph is in agreement with that given in literatures. The largest specimen had a mantle length of 16.2 $\mathrm{cm}$. for male and $15.8 \mathrm{~cm}$. for female, total length $137 \mathrm{~cm}$. for male and $130 \mathrm{~cm}$. for female and total weight $880 \mathrm{~g}$. for male and $625 \mathrm{~g}$. for female. The maximal total length recorded for the same species by Fischer, (1973) ranged from 90 to $110 \mathrm{~cm}$. Roper et al., (1984) gave greater measurements, total length $120-150 \mathrm{~cm}$., mantle length $14 \mathrm{~cm}$. and total weight $2 \mathrm{~kg}$. The smallest specimen collected during this study showed the following measurements. Total length $55 \mathrm{~cm}$. for male and $52 \mathrm{~cm}$. for female mantle length $5 \mathrm{~cm}$. for male and $4.8 \mathrm{~cm}$. for female and total weight $48 \mathrm{~g}$. for male and $40 \mathrm{~g}$. for female.

Habitat: The species lives on rocky bottoms, in crevices and holes, sometimes also on vegetated substrates (Fischer, 1973). A benthic shallow water species occurring in coral 
reefs, reef flats and on open bottoms ( Roper et al., 1984). In the present study the species was captured from muddy sandy grounds at Abu Qir Bay.

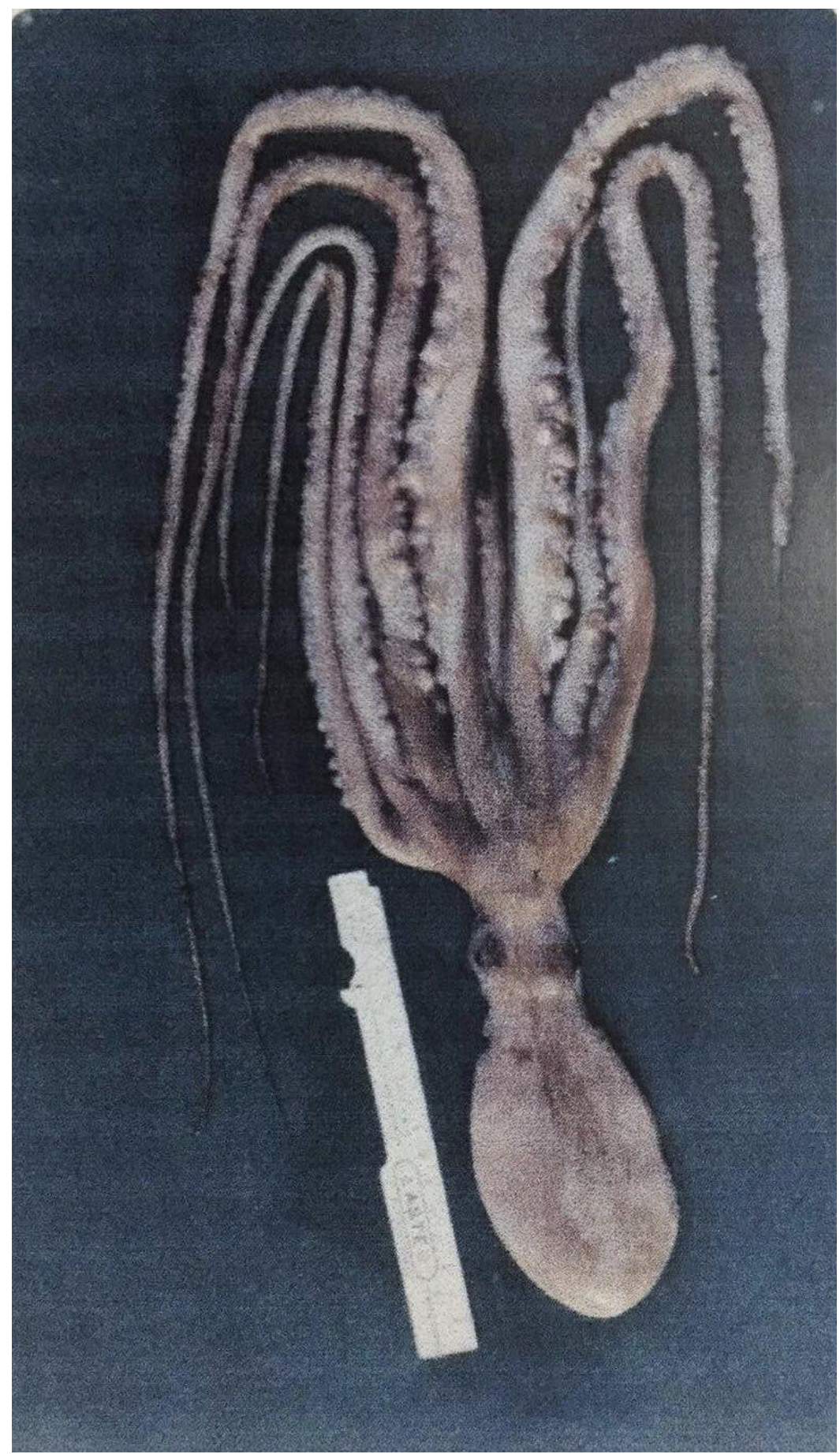

Plate (7) Octopus macropus 

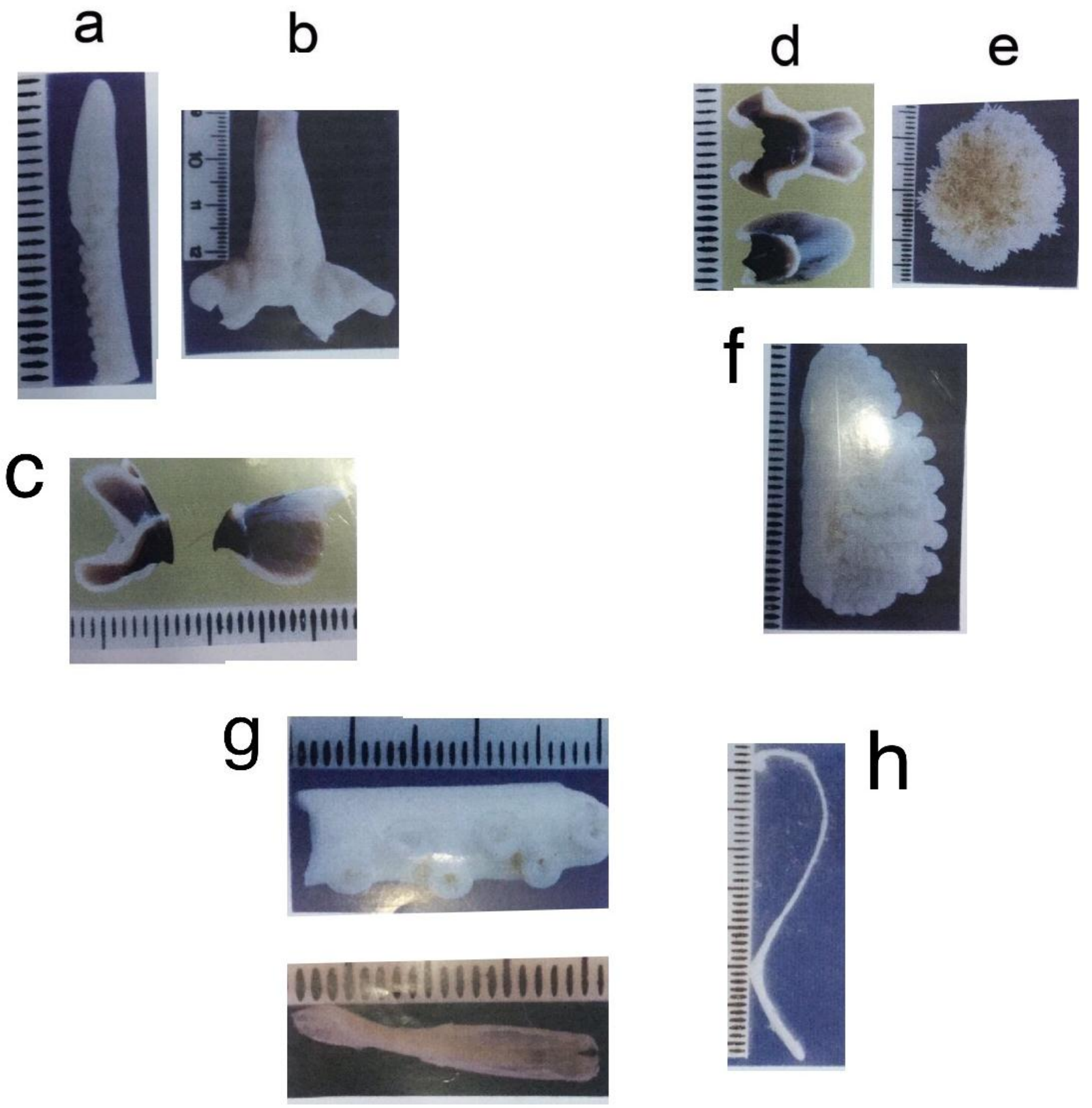

Plate (8) Octopus macropus

A- Right arm III of male hectocotylized. B- Funnel. C- Upper \&Lower beaks (lateral view). D- Upper \&Lower beaks (dorsal view).E- Egg clusters F- Gill. GPart of arm. H- Spermatophore. I- Radula. 

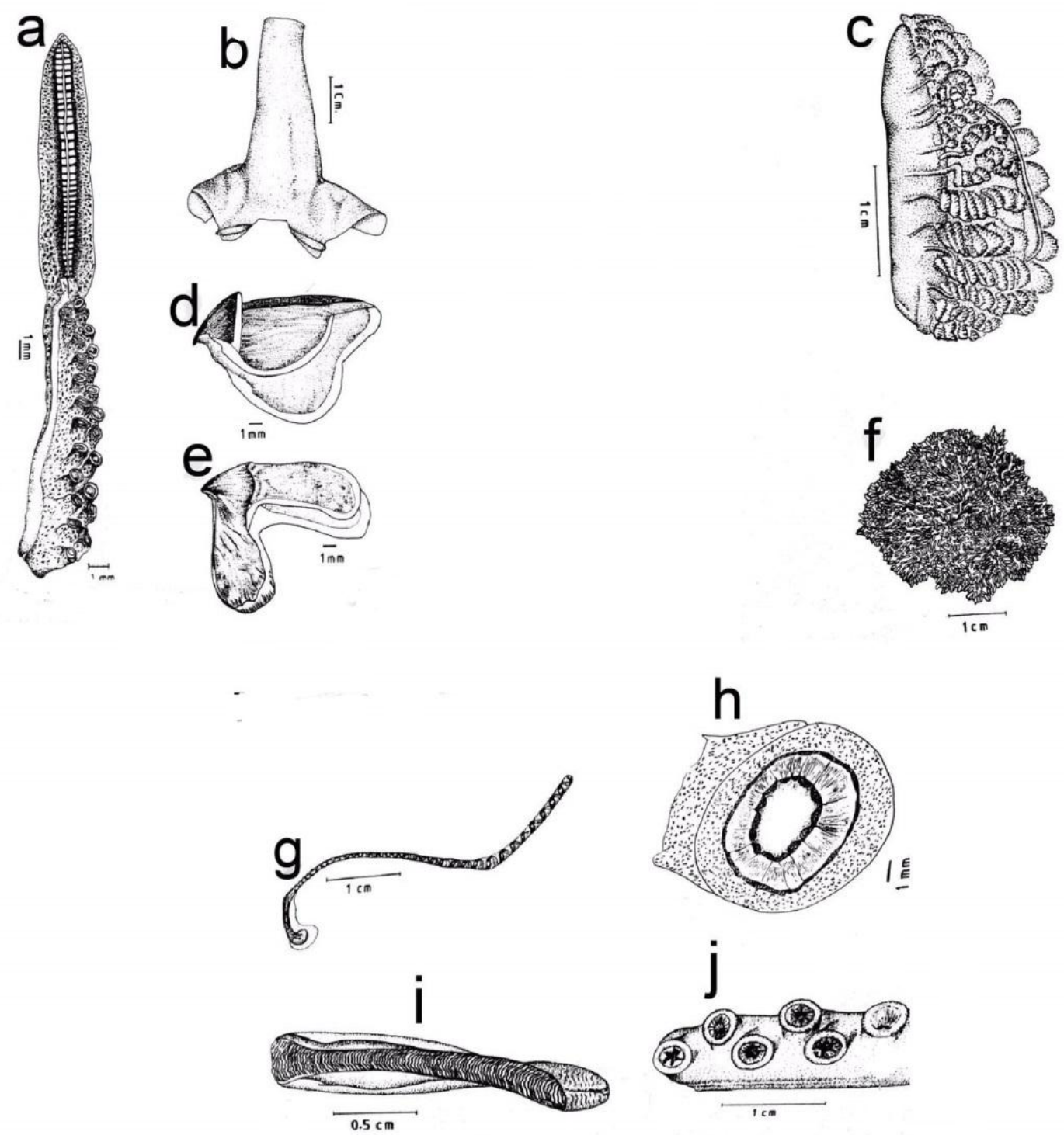

\section{Plate (9) Octopus macropus}

A- Right arm III of male hectocotylized. B- Funnel. C- Gill. d- Upper beak. eLower beak. F- Egg clusters. G- Spermatophore. H- Arm sucker. I Radula. JPart of arm 


\section{Octopous defilippi Verany, 1845. \\ (Plates 10, 11, 12\&13)}

Synonymy: Macrotritopus species. (Roper et al. 1984)

World distribution: Mediterranean Sea, Eastern Atlantic from Morocco to Angola, Cape Verde Islands, Western Atlantic, Bahamas, Gulf of Mexico, Caribbean Sea, Brazil, Indian Ocean, Arabian Peninsula to Burma and South Western Pacific (Roper, et al. 1984, Nesis (1987) and Mangold. 1998).

Local name: Okhtaboot and Sabaa deule ( Riad, 1993 ).

Local distribution: The species was encountered from Sidi Abdel Rahman locality and from commercial fish trawl from Alexandria Mediterranean waters and from Suez Gulf (Ataka Harbor) and adjacent area. It is common on Suez and Alexandria fish markets (Riad, 1993 and Riad, 2008).

Description: Mantle relatively very small, smooth-skinned, head narrower than mantle, no pigmented ocellus, spots or rings. (plate10) Funnel elongate tube (plate11c\& plate13b). All arms very long, slender, symmetrical, 3rd arms very much longer than other arms. (plate10). Arm length exceeding $70-85 \%$ of the total length, arms with delicate tips (plate $10 \&$ plate11a). Arms formula III > II >IV > I or III > IV > II > I] (plate10). Right arm III of male hectocotylized shorter than opposite arm bearing 60-100 suckers. Ligula well differentiated 1.8 to $2.5 \%$ of hectocotylized arm length, groove very shallow (plate11b, 12c\& plate13a), the gill with 8-11 gill lamellae on outer demi branch (plate11g, 12d \& plate13e). Web depth 20-25\% of the longest arm length. Web formula C $>$ D $>$ B $>$ E $>$ A (plate12f) Suckers widely set, of medium size. One cirrus over each eye (plate 12b). Funnel organ W-shaped (plate11c, 12e \& 13b).

Habitat : Inhabits bioclastic bottom at 30-60 m. depth. According to Roper et al. (1984) the species is little known as benthic species inhabiting sandy to muddy bottoms at 6 to $60 \mathrm{~m}$. water column depth, but occasionally reported down to $200 \mathrm{~m}$. (acrotritopus larva). Its larvae and juveniles are pelagic.

Present work samples showed the mantle length of the largest specimen to be $8.8 \mathrm{~cm}$. in an animal weighing $100 \mathrm{gm}$. and in the smallest specimen to be $5 \mathrm{~cm}$. in an individual weighing $30 \mathrm{gm}$., while according to Roper et al. (1984), the maximum mantle length is 9 $\mathrm{cm}$. and according to Mangold (1998), the animal is small to medium size $(3.3-5.5 \mathrm{~cm}$.) (Roper et al. 1984). Distinction of Octopus defilippi from the other Octopus spp. previously recorded in the Egyptian Mediterranean waters can be summarized as follows: Octopus defilippi: The mantle relatively very small Arm III is the largest arm and there is a cirrus over each eye. Eledone moschata: One row of suckers on each arm and clear cirrus over each eye. Octopus vulgaris: Shorter arms, a well-developed inter-branchial membrane (connecting the arms up to 1/5 of their length), and the presence of 3 cirri over each eye .Octopus macropus: Slender and longer arms, poorly developed interbranchial membrane. Cirri absent. 


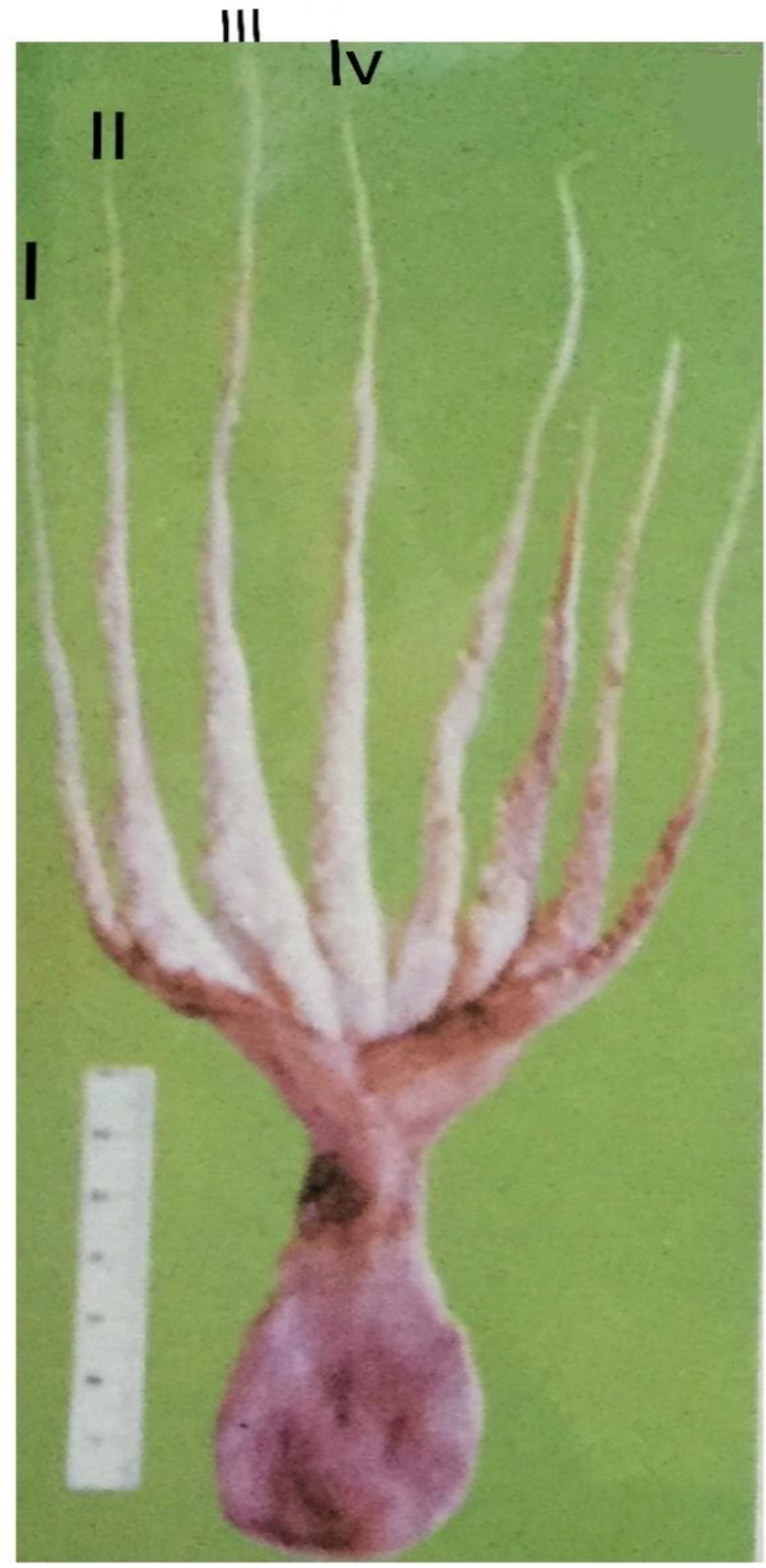

Plate (10) Octopus defilippi

Arms formula III $>$ II $>$ IV $>$ I or III $>$ IV $>$ II $>$ I] 


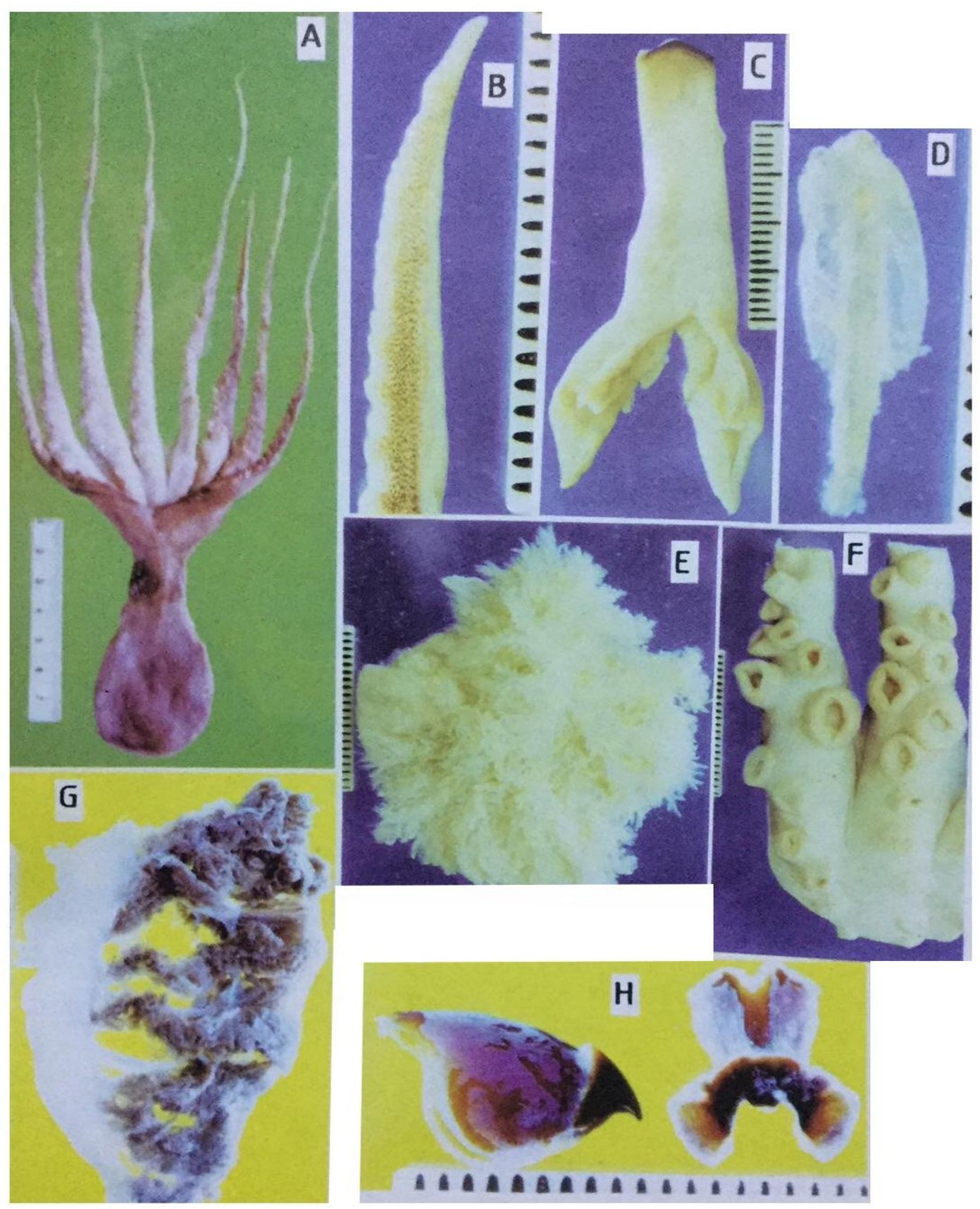

Plate (11) Octopus defilippi.

A-The animal. B- Right arm III of male hectocotylized. C- Funnel. DRadula. E-Egg clusters. F- Arm suckers. G- Gill. H- Upper and lower beaks. 

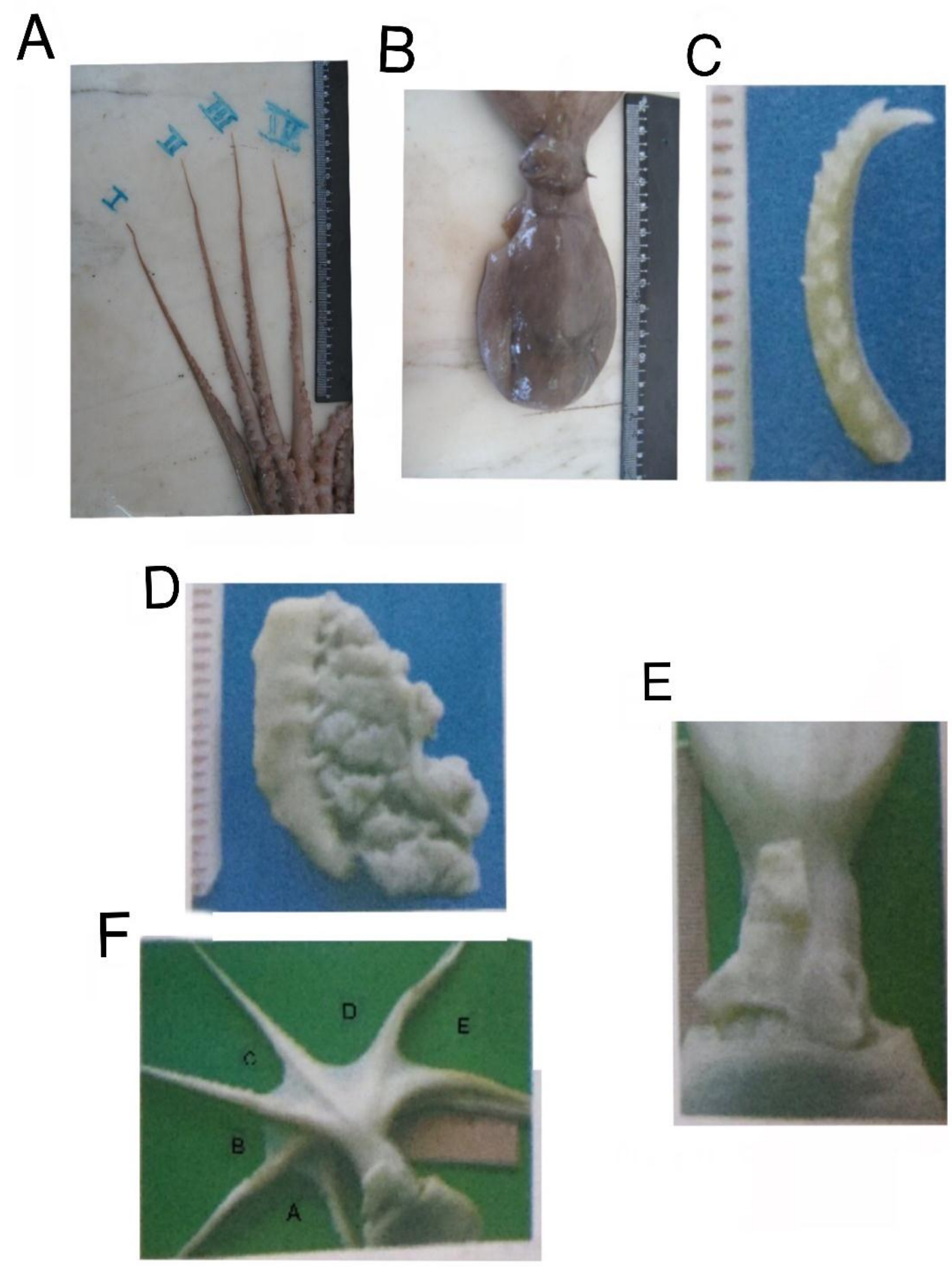

Plate (12) Octopus defilippi

A- Animal arm (arm formula). B- One cirri over each eye. C- Right arm III of male hectocotylized. D- Gill. E- Funnel. F-Arm web (Web formula). 


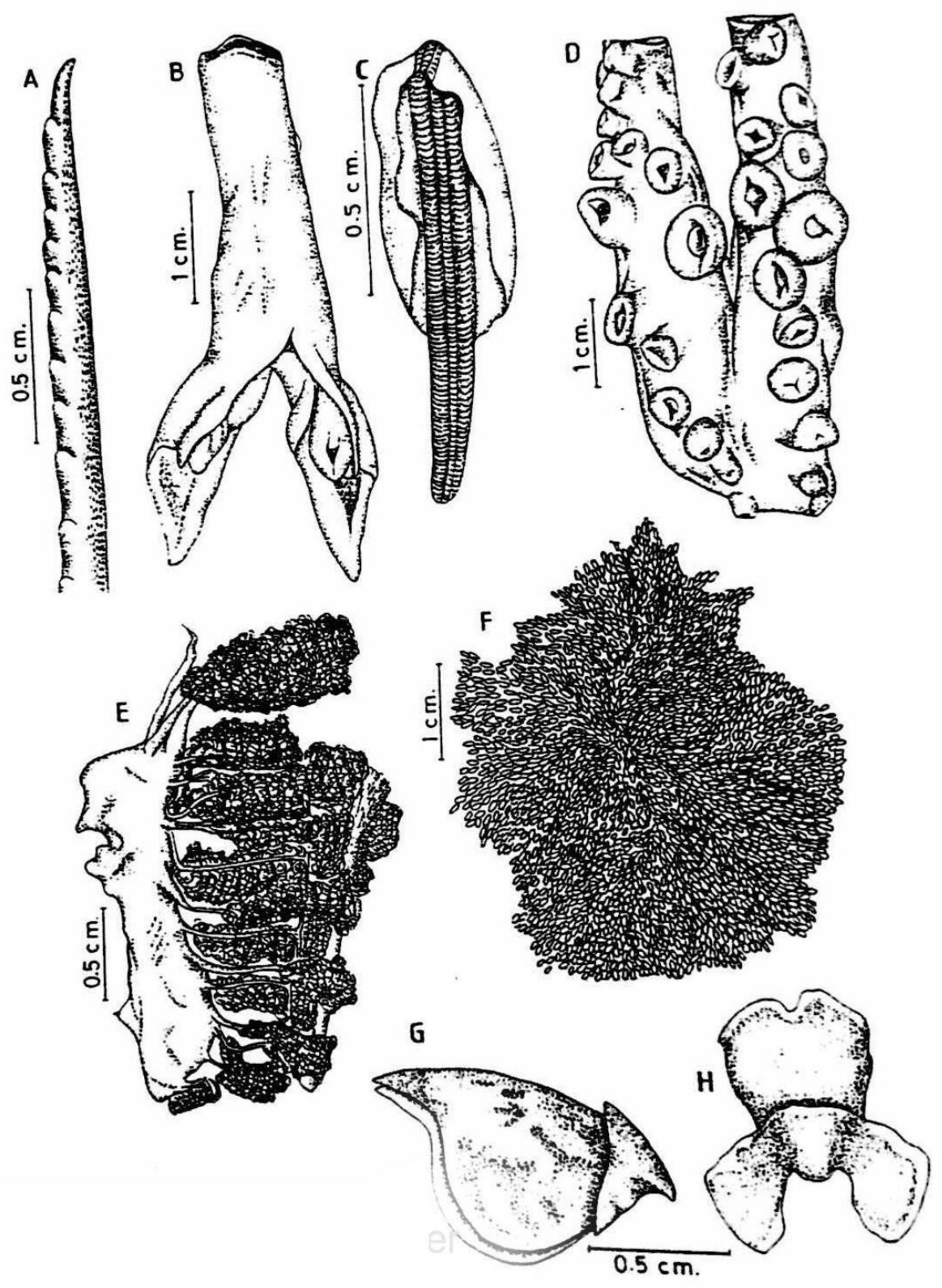

Plate (13) Octopus defilippi

A-Right arm III of male hectocotylized. B- Funnel. C- Radula. D- Arm suckers. E- Gill. F- Egg clusters. G- Upper beak. H- Lower beak. 


\section{Octopus aegina Gray, 1849 \\ (Plates: 14\&15)}

Material: 32 individuals with dorsal mantle length range from $2.5 \mathrm{~cm}$. to $4.2 \mathrm{~cm}$. Were collected from Suez Gulf, Red Sea.

Synonymy: Octopus kagoshimensis, Ortmann, 1888. (Roper et al., 1984)

Local name: Okhtaboot (Riad, 2008).

Local distribution: Suez Gulf, Red Sea (Riad, 2008 \&Osman et al.,2014).

World distribution: Western Pacific, Indian Ocean, Red Sea, Japan to Mozambique from 30 to 120 meter. (Roper et al., 1984).

Description: Mantle rounded to oval, covered with fine papillae arranged in a Reticulate Pattern, Single cirrus over each eye. Arms long, arms I are shortest (plate $14 \&$ plate 15a). The web very shallow between arms I. Right arm III of male hectocotylized with short ligula, 5 to $8 \%$ of arm length and ligula with very shallow groove (plate15c).Seven gill lamellae per cach gill (plate15b). The morphological description of Octopus aegina was in agreement with Adam (1959 and 1960) from Gulf of Suez and Gulf of Aqaba. The morphology of Octopus aegina in the present study is in agreement with the literatures, except Adam, 1960 which recorded that, the gills have eight filaments in each demibranch and in the present work the dorsal mantle length showed the largest specimen to be $4.2 \mathrm{~cm}$. and the smallest specimen to be $2.5 \mathrm{~cm}$., while according to Roper et al., (2984) the maximum dorsal mantle length is $10 \mathrm{~cm}$.

Habitat: A benthic, not highly cryptic species, common on the continental shelf from 30 to $120 \mathrm{~m}$. depth. (Roper et al., 1984). 


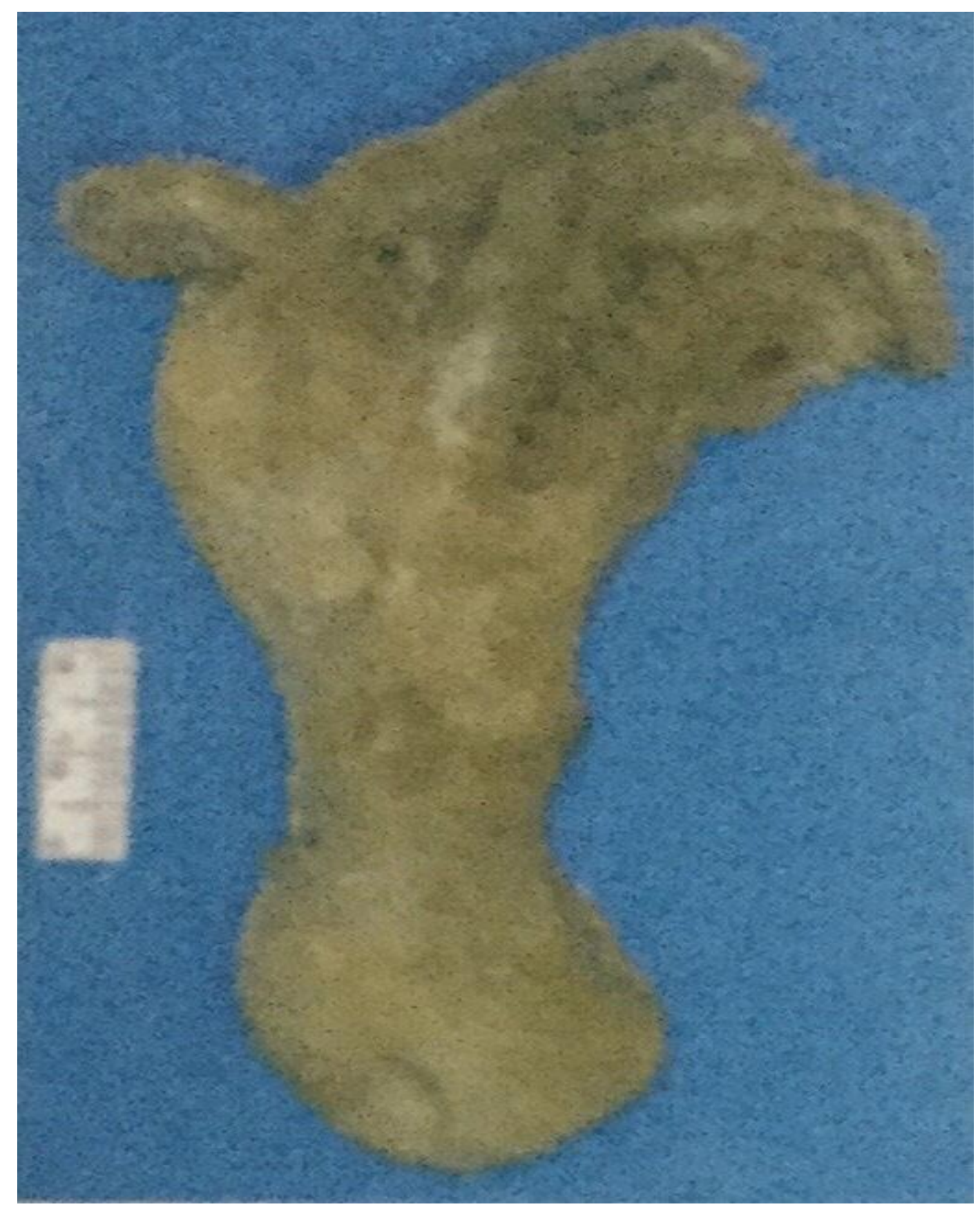

Plate (14) Octopus aegina 

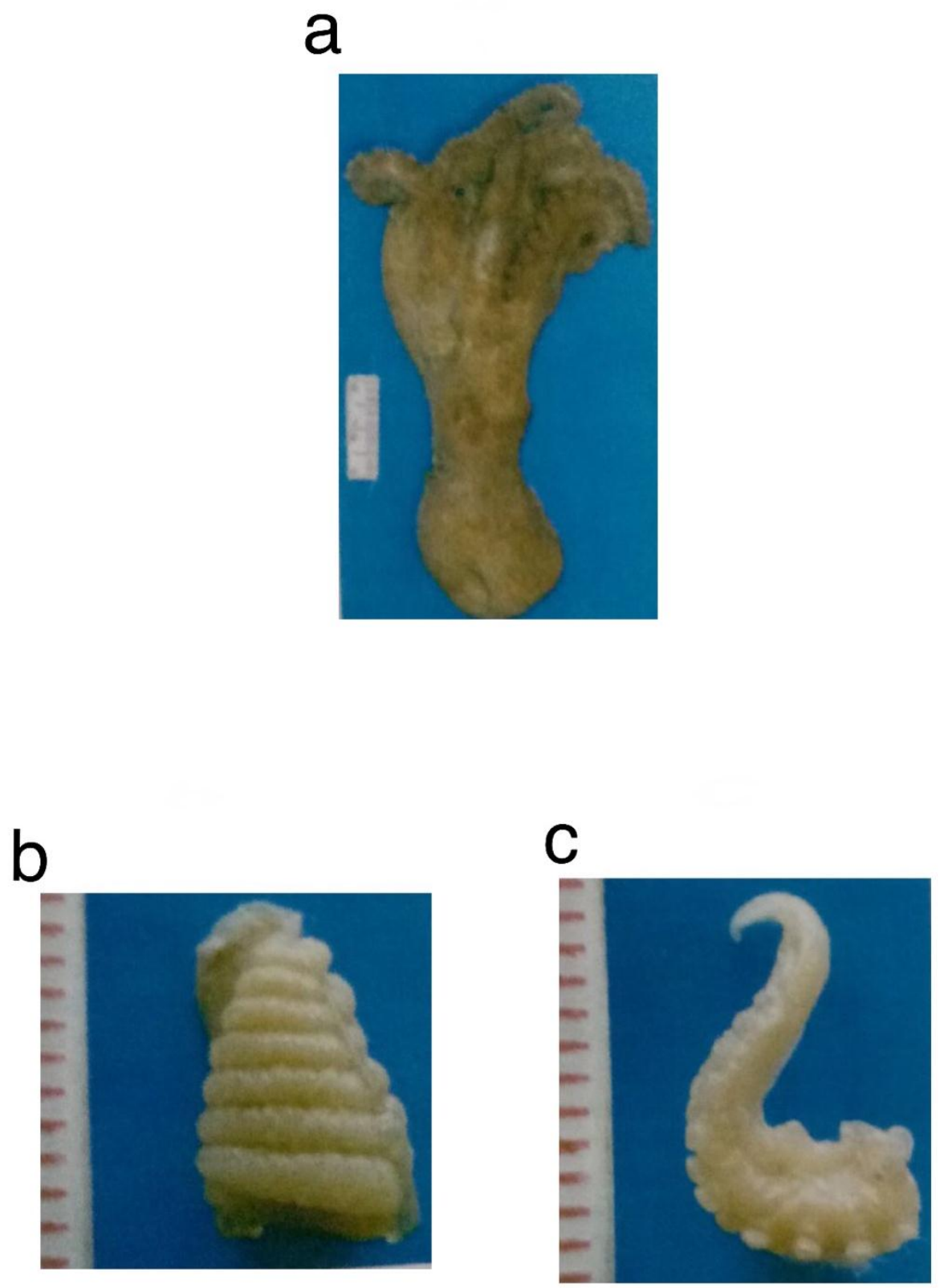

\section{Plate (15) Octopus aegina}

A-The animal. B-Gill. c- right arm III of male hectocotylized. 


\section{Octopus membranaceus Quoy\& Gaimard, 1832}

\section{(Plates: 16 \& 17)}

Materials: Nine individuals with dorsal mantle length range from $4.2 \mathrm{~cm}$. to $5.5 \mathrm{~cm}$. Were collected from commercial fish trawl from Suez Gulf (Ataka Harbor) and adjacent area. Synonymy: Octopus fang- siao Orbigny, 1940; Octopus ocellatus Gray, 1849. (Roper et al., 1984 ).

World distribution: Indo - Pacific, Indian Ocean to Japan, China, Philippines and ward South to Australia. (Roper et al., 1984).

Local name: Okhtaboot (Riad, 2008).

Local distribution: Suez Gulf, Red Sea (Riad, 2008).

Description: Mantle elongate. Two cirri over cach eye. Arms moderately long. Web short (plate 16 \& plate17a). Ringed ocellus on web at base of arms II, antero ventral to the eyes (17c).Right arm III of male hectocotylized: ligula slender and long 4 to $6 \%$ of arm length. (Plate 17b). Seven or eight gill lamellae in gill (plate 17d). The morphology of Octopus membranaceus in the present study is in agreement with the literatures, apart from, the gill with 7 or 8 gill lamellae and in the present work the dorsal mantle length showed the largest specimen to be $5.5 \mathrm{~cm}$. and the smallest specimen to be $4.2 \mathrm{~cm}$. According to Roper et al., (1984) maximum mantle length $8 \mathrm{~cm}$.

Habitat: A benthic shallow- water species occurring down to about $60 \mathrm{~m}$. depth. It shows a strong cryptic behavior and usually hides on flat bottoms. (Roper et al., 1984). 


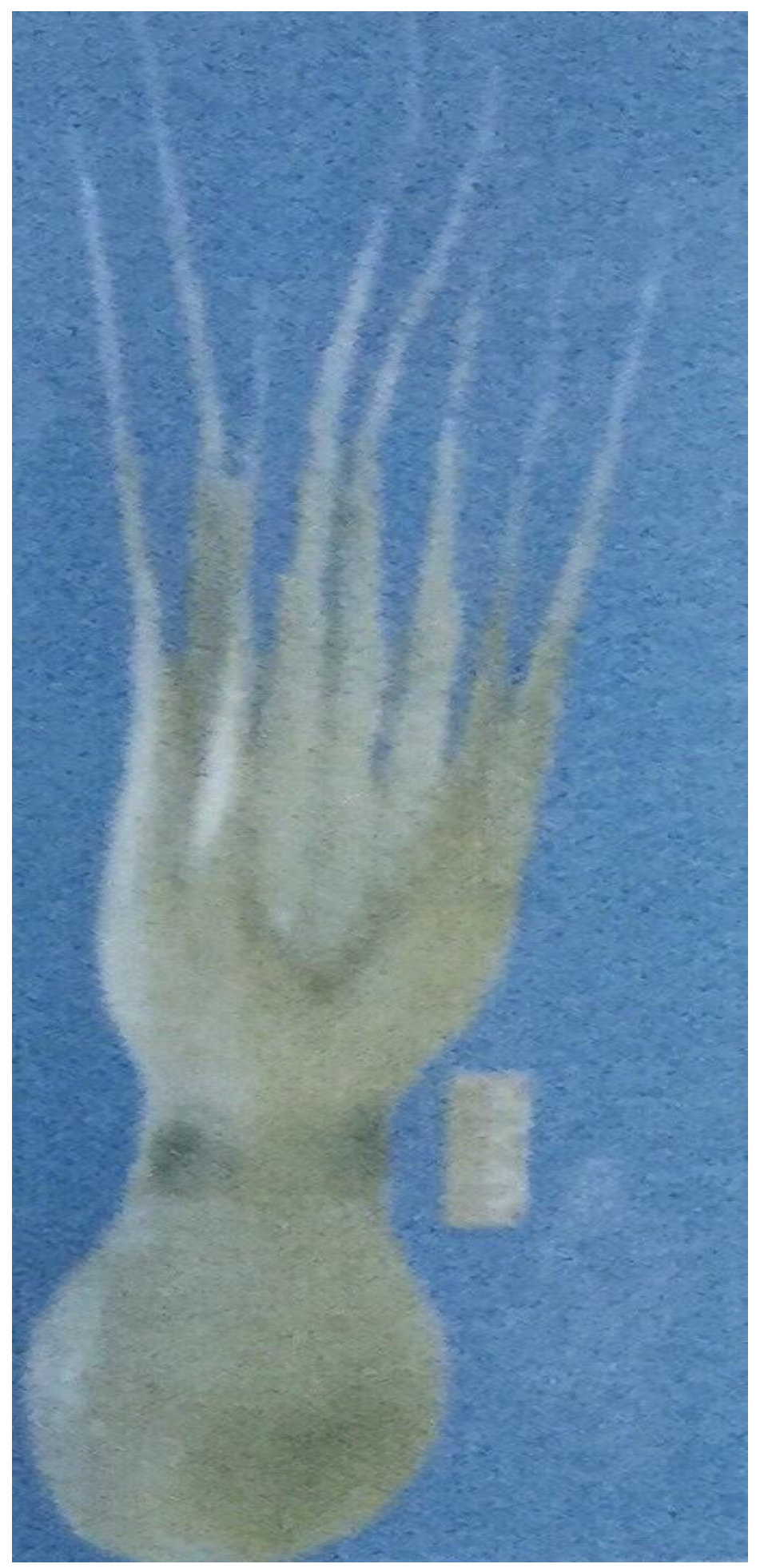

Plate (16) Octopus membranaceus 

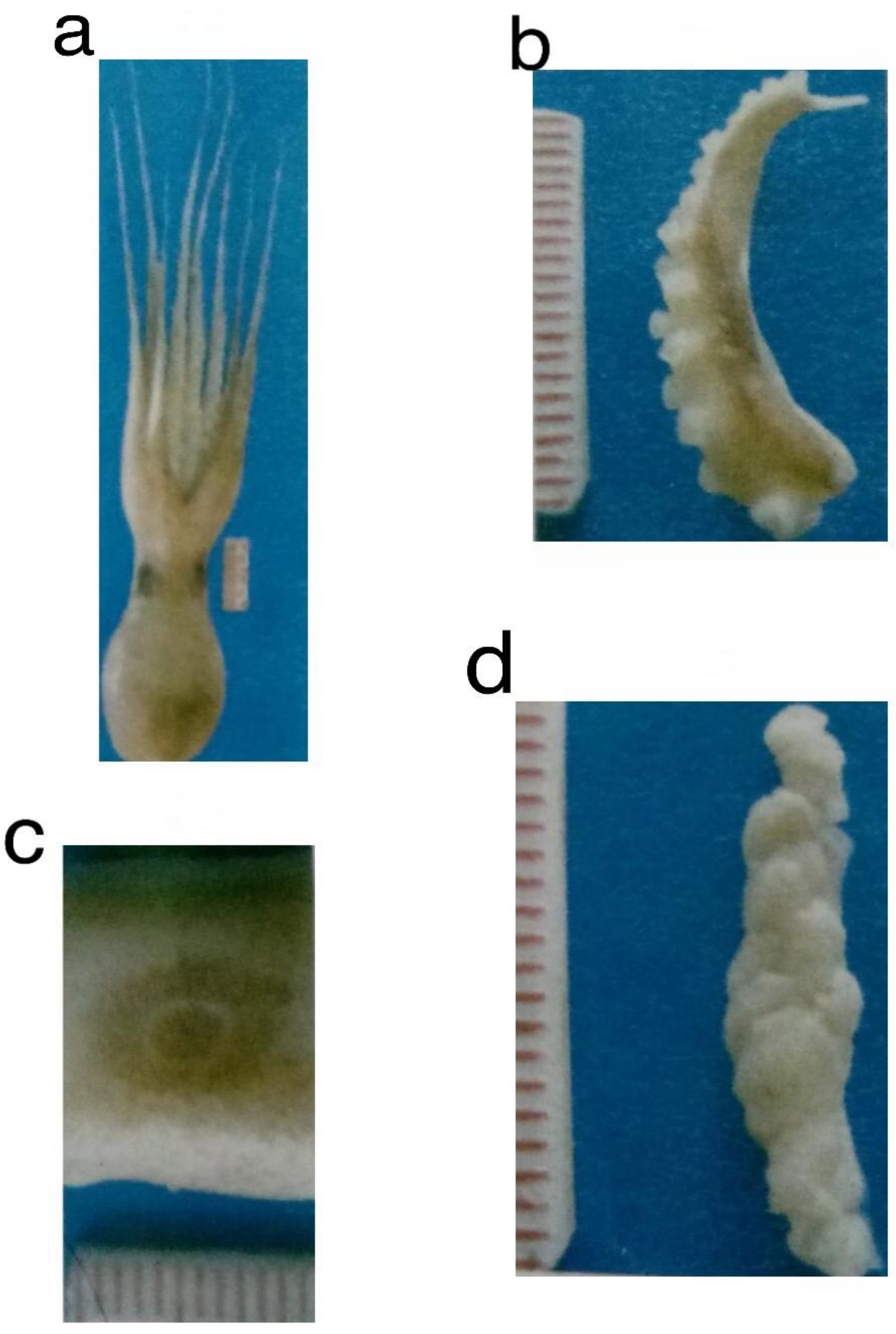

PLATE (17) Octopus membranaceus

a- The animal. b- Right arm III of male hectocotylized. c-Ringed ocellus on web at base of arm II, anteroventral to the eyes d- Gill. 


\section{ACKNOLEDGMENT}

I appreciate Dr. Safaa Fahmy, Dr. Marina Rafik and Miss Shery Rafik for their kind cooperation. I am grateful to Dr. Magdy Khalil, professor of Aquatic Ecology, Faculty of Science, Ain Shams University for his sound supervision and support and for his helpful suggestions. I am indebted to Dr. Raouf Kilada, Professor of Biological Oceanography, University of New Brunswick, Saint John, for his assistance, he kindly offered.

\section{REFERENCES}

Adam, W. (1959). Les cephalopods de la mer Rouge Resultats scientifiques. Mission Robert Ph. Dollfus en Egypt. CNRS, Paris. pp. 125-192.

Adam, W. (1960). Cephalopoda from the Gulf of Aqaba. Bull.Sea. Fish. Res. Stn. Haifa. Vol., 26: 1-27.

Akimushkin, I.I. (1963). Cephalopods of the Seas of the USSR 235 page. Moscow: Academy of Science of the USSR, Institute of Oceanology. [In Russian]. English translation. 1965, 223 pages.Jerusalem: [Israel program for Scientific Translations].

Anonymous (1986-1998). Yearbook of fisheries statistics. National Institute of Oceanography and Fisheries, Alexandria, A.R.E. (In Arabic).

Byles, R.H.; McGuire W. ; Sanders, M. F. (1979). Methods of isoelectric focusing. Am. J. Phys. Anthrop. 50: 27-34.

Clarke, M. R. (1962).The identification of cephalopod "beaks" and the relationship between beak size and total body weight. Bulletin British Museum History Zoology,8:449-480.

Clarke, M. R. (1966). A review of the systematic and ecology of oceanic squids. Advances in Marine Biology, 4: 93-223.

Elganainy,A.A.and Riad,R.( 2008).Population structure of Octopus defilippi (Verany, 1851) from the Gulf of Suez. Egypt. J. Aquatic. Research 12 (2): 81-91.

Emam, W.M.; Ibrahim, A.M.; Ghareb, T. (2008). Macro and microscopic structure of the digestive system of Octopus vulgaris from Alexandria water on the Mediterranean Sea. J. Egypt. Acad. Soc. Environ. Develop., (D- Environmental Studies), 9 (2): 141-154.

Fischer. (E., (1973). FAO species identification sheets for fisheries purp, Mediterranean and Black Sea (Fishing area37). Rom FAO. Vol.2:pag. Var.

Forbes, E. and Hanley, S. (1852). Ahistory of the British Mollusca and their shells. London. 4: 207-243.

Hochberg, F.G.; Nixon, M. ; Toll, R.B.( 1992). Order Octopoda Leach, 1818. In M.J. Sweeney, C.F.E. Roper, K. Mangold, M.R.Clarke and SV. Boletzky, editors. "Larval" and juvenile cephalopods: A Manual for their identification. Smithsonian Contributions to Zoology 513: 213-271.

Ibrahim, A.M.; Emam, W.M.; Kenchington, E.; Ghareb,K. T. (2006). Mollecular phylogeny of three octopodid species from the Mediterranean water, Egypt. Egypt. J. Aquat. Biol. and Fish., 10(4):163-179.

Katagan, T. and Kocatas, A. (1990). Note preliminaire sur les cephalopods des Eaux Torques. Rapp. Comm. Int. Mer. Medit., 32, 1: 242.

Mangold, K. and Fioroni, P. (1966). Morphologie et biometrie des mandibules de quelques Cephalopodes Mediterranean's. Vie milieu 17(A): 1139-1196. 
Mangold, K. (1998). The Octopodinae from the Eastern Atlantic Ocean and the Mediterranean Sea. In (Systematic and Biogeography of Cephalopods Volume II) in Smithsonian Contributions to Zoology. Number 586: 521-528.

Massy, A.L. (1928). On the Cephalopoda of the Natal Museum. Ann. Natal Mus, Part 2, 6 (1): 89-96+ Plate. Bull. Nat. Inst. of Oceanogr. \& Fish., A.R.E. 26: 167- 182.

Nesis, K.N. (1987). Cephalopods of the world. Squid, cuttlefishes, octopuses, Neptune City, NJ: T.F.H. Publications Inc., Ltd, 351 pp.

Nessim,A.B.and Riad,R. (2003).Bioaccumulation of heavy metals in Octopus vulgaris from coastal waters of Alexandria (Eastern Mediterranean) Chemistry and Ecology 19 (4): 275-281.

Osman,I.H.; Howaida R. Gabr,H.R.; Salah G. El-Etreby,S.,G.; Saad Z.; Mohammed,S.,Z. (2014). studied the Feeding biology and biochemical composition of the lessepsian migrant Octopus aegina (Cephalopoda: Octopodidae. Egypt. J. Aquat. Biol. \& Fish., 18 ( 2): $15-27$.

Riad, R. (1993). Studies on cephalopod molluscs of the Mediterranean waters of Alexandria. M. Sc. Thesis, Ocean. Dept., Fac. Sci., Alex. Univ., 246 pp.

Institute of Oceanography and Fisheries, Alexandria. 167 pp.

Riad, R. (2000a). Biological and taxonomical studies on octopuses (Octopoda: Cephalopoda) from the Egyptian Mediterranean waters Ph. D. Thesis, Faculty of Science, Alexandria University, Egypt, 236 pp.

Riad, R. (2000b). First record of Rossia macrosoma and Octopus defilippi (Cephalopoda: Mollusca) in the Egyptian Mediterranean waters

Riad, R. (2008). Morphological and taxonomical studies on some cephalopods from the Suez Gulf and Red Sea. Egypt. J. Aquatic. Research, 34 (1): 176- 201.

Riad,R.(2020a)MonographoftheEgyptianCuttlefishesOrder:Sepiodea(Cephalopoda: Mollusca) Part I.

Riad,R.(2020b)MonographoftheEgyptianSquidsOrder:Teuthoidea(Cephalopoda: Nn Mollusca) PartII.

Riad, R.; Wadie, W.F. ; Halim, Y. (1997). Development of Octopus vulgaris, Lamark from Egyptian Mediterranean waters. Bull. Nat. Inst.of Oceanogr. \& Fish. A.R.E. Vol. (23): 389-411.

Riad, R. and Gabr, H.R. (2007). Comparative study on Octopus vulgaris (Cuvier, 1797) from the Mediterranean and Red Sea coasts of Egypt.

Riad, R. and Kilada, R. (2012). Reproductive biology of the musky octopus Eledone moschata (Cephalopoda: Octopodidae) in the Eastern Mediterranean, Egypt.J.Aquatic.Biol and Fish 16(4):1-13

Riedle, R. (1970). Fauna und flora der Adria.pp. 463 - 469.

Robson, G. C. (1912). The Biogeography and Numerical Taxonomy of the Oegopsida.

Robson, G. C. (1926). Report on the Mollusca ( Cephalopoda). Cambridge Expedition to the Suez Canal., pp. 321-329.

Robson, G. C. 1929. A monograph of the recent Cephalopoda based on the collections of the British Museum (Natural History) Part I. Octopodinae, 236 pages. London: British Museum (Natural History). collections of the British Museum (Natural History) Part I. Octopodinae, 236 pages. London: British Museum (Natural History).

Robson, G. C. (1930). Cephalopoda, 1. Octopoda "Discovery" Rep. 2: 373-401 + 2 Plates. 
Robson, G.C. (1932). A monograph of the recent Cephalopoda. Part 2. The Octopoda. (Excluding the Octopodinae): 359 pages. London British Museum (Natural History).

Roeleveld, M. A. (1975). A revision of Massy's checklist of South African Cephalopoda. Ann. S. Afr. Mus. 66(11): 233-255.

Roper, C.F.E.; Sweeny, M.J. ; Nauen, C.E. (1984). Cephalopods of the world. FAO Fisheries Synopsis 3 (125). 51-52 pp.

Saad, A. H. A. and Emam, W. M. (1998). Studies on poisonous salivery glands of Octopus vulgaris from the Mediterranean Sea. Proc. Egypt, Acad. Sci., 48: 81-93.

Steuer, A. (1939). The fishery grounds near Alexandria. XIX -Mollusca. Notes and Memoirs, No. 33: 1-152.

Villanueva, R.; Sanchez, P.; Compagno Roeleveld, M. A. (1992). Octopus magnificus (Cephalopoda: octopodidae), a new species of large octopod from the southeastern Atlantic. Bulletin of Marine.

Voss, G. L. (1967). Some bathypelagic cephalopods from South African Waters. Annals of the South African Museum, 50 (5): 61-88. 